\title{
Microsporogenesis and Microgemetogenesis in a Cryptoviviparous Mangrove Species- Aegiceras corniculatum (L.) Blanco
}

\author{
Pandey R. ${ }^{1} \&$ Pandey C. N. ${ }^{2}$ \\ ${ }^{1}$ Project Coordinator-Climate change studies, GIPL, Gujarat Forest Department, Aranya Bhavan, 3rd Floor, B \\ wing, Opp. St. Xavier School, Near Cha-3, Sector 10, Gandhinagar, 382010, Gujarat, India \\ ${ }^{2}$ Principal Chief Conservator of Forest, (wildlife), Aranya Bhavan, 3rd Floor, B wing, Opp. St. Xavier School, \\ Near Cha-3, Sector 10, Gandhinagar, 382010, Gujarat, India \\ Correspondence: Pandey R., Project Coordinator-Climate change studies, GIPL, Gujarat Forest Department, \\ Aranya Bhavan, 3rd Floor, B wing, Opp. St. Xavier School, Near Cha-3, Sector 10, Gandhinagar, 382010, Gujarat, \\ India. E-mail: richa81181@yahoo.co.in
}

Received: February 5, 2013 Accepted: May 5, 2013 Online Published: May 11, 2013

doi:10.5539/jps.v2n3p53 URL: http://dx.doi.org/10.5539/jps.v2n3p53

\begin{abstract}
Owing to the special feature-vivipary-most of the embryological studies on mangroves pertain to megasporogenesis, megagametogenesis and post fertilization developments. The mircosporogenesis and microgemetogenesis aspects are largely remained unexamined for mangroves. The present work examines microsporogenesis and microgemetogenesis of a cryptoviviparous mangrove species-Aegiceras corniculatum (L) Blanco- (Myrsinaceae). The present work was based on the assumption that morphological features are, in fact, manifestation of the histological developmental processes. Thus, morphologically distinct developmental stages of buds were selected and examined through microtomy technique using light microscope and they have shown distinct developmental stages of stamen and/or pollen grains. The anthers are tetrasporangiate and septate (multillocetale). The three layers of microsporangium i.e. endothecium, middle layer and tapetum are present. The endothecium develops fibrillar thickenings prior to anther dehiscence. In addition to the endothecial cells, other vegetative cells also develop fibrillar thickenings which facilitate anther dehiscence. Tannin content is very high in epidermal layer of anther lobes. Tapetum is secretary type. Meiosis is simultaneous type with tetrahedral type of tetrad. Pollen is bi-nucleated at the time of anther dehiscence.
\end{abstract}

Keywords: mangrove, endothecium, tapetum, microspore tetrad, mircosporogenesis, microgemetogenesis, meiosis and pollen grains

\section{Introduction}

The distribution of mangrove genera over taxonomically distant families indicates their convergent evolution from unrelated terrestrial ancestors. It had led to a number of developmental/embryological (Juncosa, 1982; Juncosa, 1984; Farnsworth, 2000) and palynological studies (Grindrod, 1985; Jaramillo \& Bayona, 2000; Plaziat, Cavagnetto, Koeniguer, \& Baltzer, 2001; Rull, 2001) on mangrove. Therefore, the ontogeny of many mangroves had been studies (Cook, 1907, Carey \& Fraser, 1932; Carey, 1934; Juncosa, 1982; Juncosa, 1984). Further, most of such works are largely dealt with the seed biology owing to special feature such as vivipary and other seedling peculiarities (Tomlinson, 1986). Vivipary can be categorized as true vivipary and cryptovivipary (Tomlinson, 1986). True vivipary (i.e. continuous growth of embryo) results in the rupture of seed coat and fruit wall as is reported in the mangrove species belonging to the family tribe Rhizophorae. In cryptovivipary, the developing embryo does not break the fruit wall and is reported in many mangrove species belonging to the families Avicenniaceae, Myrcinaceae etc. Owing to this special feature, most of the embryological studies on mangroves pertain to megasporogenesis, megagametogenesis and post fertilization developments. The mircosporogenesis and microgemetogenesis aspects are largely remained unexamined for mangroves.

Aegiceras corniculatum L. (Blanco) (hereafter referred as A. corniculatum) belongs to the family Myrsinaceae and is generally found in the estuarine mangrove forests in the tropical and sub-tropical regions (Tomlinson, 1986; Kathiresan \& Rajendran, 2005; Duke, 2006; Pandey, C. N. \& Pandey, R., 2009). The development of embryo in A. corniculatum has been studied by (Carey \& Fraser, 1932). The embryological studies on other members of Myrcinaceae family have also been carried out in past (Dahlgren, 1916; Schurhoff, 1926). Rao 
(1971) has studied the embryology of Maesa dubia Wall. (another member of this family). Karsten (1891) has reported septate anther in A. corniculatum. Tomlinson (1986) had also mentioned the structural details of few mangroves genera. However, the mircosporogenesis and microgemetogenesis of $A$. corniculatum could not get attention of the researchers. Being an essential part of the developmental biology, these aspects also need to be examined. Therefore, the present work examines different aspects of mircosporogenesis (development of microsporangia) and microgemetogenesis (development of pollen grains) for A. corniculatum. It also throws lights on anther dehiscence process and the structure of pollen grains for the selected mangrove species.

\section{Materials and Methods}

The present work was based on the assumption that morphological features are, in fact, manifestation of the histological developmental processes. Thus, morphologically distinct developmental stages of buds were selected. As per authors' understanding, such approach has yet not been applied for any mangrove species to examine the mircosporogenesis and microgemetogenesis. The buds of $A$. corniculatum were categorized into seven floral stages i.e. Z-1, Z-2, O-1, O-2, O-3, O-4 and O-5 (Table 1).

Table 1. Details of the different developmental stages

\begin{tabular}{|c|c|c|c|c|c|}
\hline $\begin{array}{l}\text { Sr. } \\
\text { No. }\end{array}$ & $\begin{array}{l}\text { Developmental } \\
\text { stages }\end{array}$ & Photographs & $\begin{array}{l}\text { Sr. } \\
\text { No. }\end{array}$ & $\begin{array}{l}\text { Developmental } \\
\text { stages }\end{array}$ & Photographs \\
\hline 1 & Z-1 & & 5 & $\mathrm{O}-3$ & \\
\hline 2 & Z-2 & & 6 & O-4 & \\
\hline 3 & O-1 & & & & \\
\hline & & & 7 & O-5 & \\
\hline 4 & $\mathrm{O}-2$ & & & & \\
\hline
\end{tabular}

For mircosporogenesis, the samples of each developmental stage were collected, preserved in three fixatives i.e. Carnoy's Fluids fixative (Alcohol $30 \mathrm{ml}$, Glacial acetic acid $5 \mathrm{ml}$ and Chloroform $15 \mathrm{ml}$ ), Petrunkevistch's Fluid ( $40 \%$ ethanol $125 \mathrm{ml}$, Glacial acetic acid $27.5 \mathrm{ml}$, Concentrated Nitric acid $2.5 \mathrm{~mm}$ and Mercuric chloride up to saturation) and Formalin-Acetic acid-Alcohol (70\% ethyl alcohol $90 \mathrm{ml}$, glacial acetic acid $5 \mathrm{ml}$ and formalin 5 $\mathrm{ml}$ ) separately for $24 \mathrm{hrs}$. Since, the microsporogenesis of any mangroves species has not been studied; any preservative has not been standardized for them. Therefore, more than one preservative were used for sample preservation.

The fixed samples were embedded in wax using standard methods of wax embedding and serially sectioned using a rotary microtome (Jensen, 1962). Sections were stained with Periodic acid Schiff (PAS) for insoluble polysaccharides (Hotchkiss, 1948; McManus, 1948) and Toludine blue stains and subsequently dehydrated through an alcohol series and then mounted in DPX mountant. The sections of $15 \mu \mathrm{m}$ thickness were taken. The 
microscopic examination was carried out using an Olympus photomicroscope with normal bright field optics.

For microgemetogenesis, samples of O-3, O-4 and O-5 were collected early in the morning (between 5:00 am to 6:00 am) and preserved in $2 \%$ Gluteraldehyde solution. The squash method was used and samples were stained with decolorized aniline blue and observed under florescent microscope.

\section{Observations}

The buds of stage Z-1 take 15 to 40 days to attain the maturity of O-5 stage which corresponds to the cumulative period of mircosporogenesis and microgemetogenesis. The seven developmental stages (Z-1 to O-5) have shown distinct stages of the mircosporogenesis and microgemetogenesis processes and supported the assumption that morphological features are manifestation of histological processes. The developmental stage of mircosporogenesis/microgemetogenes is observed in seven developmental stages are summarized as follows:

\subsection{Stamen Primordia-Homogenous Mass of Cells (Developmental Stage Z-1)}

The stamen primordia were composed of homogenous mass of cells surrounded by an epidermal layer in the buds of Z-1 stage (Figure 1.1 A). The stamens are attached with petal at base (Figure $1.1 \mathrm{~A}$ ). Initially the filament and anther lobes were indistinguishable. However, in the subsequent development, the anther lobe gets widen due to anticlinal cell divisions. The stamens are arranged opposite to petals (Figure 1.1 B)

\subsection{Archesporial Initial Cells (Developmental Stage Z-2)}

In the buds of floral stage Z-2, four constrictions appear on its peripheral surface which eventually results into four lobed anthers (Figure1.1 B). One or two hypodermal cells in each anther lobe (or microsporangium) started enlarging. These cells are distinguishable from the remaining hypodermal cells by their size, dense cytoplasm and prominent nuclei and act as archesporial initial cells (Figure 1.1 C). These archesporial initial cells divide periclinally to form outer primary parietal cell (PPC) (Figure 1.1 D) and the inner primary sporogenous cell (PSC). The primary parietal cell divides periclinally and anticlinally to form the different wall layers of microsporangium viz. endothecium, middle layers and tapetum. The primary sporogenous cells further divide and form sporogenous cells (Figure 1.1 D).

\subsection{Anther Wall Layers (Developmental Stage Z-2 and O-1)}

The development of the anther wall has been reported in the buds belonging to Z-2 and O-1 floral stage. The primary parietal cells (PPC) divide periclinally and form secondary parietal cells. The secondary parietal cells divide periclinally and anticlinally. During subsequent developments, the outer secondary parietal cells develop into endothelium and the inner secondary parietal cells form middle layer and tapetum.

\subsubsection{Epidermis}

Initially, the epidermal cells are small. But, in the mature anther, they get enlarged and they were found to contain tannin (Figure 1.1 $\mathrm{F}$ and $\mathrm{H}$ ) except at four constrictions (Figure 1.2 A) where these epidermal cells remain small and flattened while the remaining cells enlarge and become rectangular (Figure 1.2 A and F). These flattened cells, between two microsporangia of the same lobe, disintegrate at the time of anther dehiscence (Figure 1.2 G).

\subsubsection{Endothelium}

The endothelium is single layered and is composed of enlarged cells which are tangentially elongated (Figure 1.2 $\mathrm{G}$ and $\mathrm{H}$ ). The endothelium cells develop from the secondary parietal layer and cover the microsporangium completely. The cells of the endothelium are radially elongated and attain their maximum development at the time of anther dehiscence. Transverse as well as longitudinal fibrillar thickenings, secondary deposition on the cell wall, in these cells were found in completely matured anthers i.e. in the buds of St-1 (Figure $1.2 \mathrm{G}$ and $\mathrm{H}$ ). The endothecial cells are filled with tannin except at four constrictions of the anther lobes (Figure 1.2 A, F and $\mathrm{G})$. A separation layer is formed at the time of anther dehiscence (Figure 1.2 G).

\subsubsection{Middle Layers}

Below the endothecium, 2-3 middle layers are present in A. corniculatum (Figure1.1 E). The cells of middle layer have starch grains which are utilized in the development of pollen grains.

\subsubsection{Tapetum}

The tapetum is single layered (Figure 1.1 E, G and H) and is located inner to the middle layer. The tapetal cells are elongated and have dense cytoplasm and prominent nuclei (Figure 1.1 E, G and $\mathrm{H}$ ). This layer surrounds the sporogenous cells completely (Figure 1.1 E, G and H). The tapetal cells facilitate the development of exine and intine of pollen grains and also meet the nutritional requirement of the developing pollen grains. The tapetum is 
of secretory type. The inner wall of the tapetum develops some pores to secrete the nutrition for the developing pollen grains. The tapetum cells do not disintegrate completely. However, their cellular integrity sustains till the formation of microspore mother cells and initiation of meiotic division (Figure 1.1 H). Later on, the tapetum disintegrates (Figure $1.2 \mathrm{G}$ and $\mathrm{H}$ ).
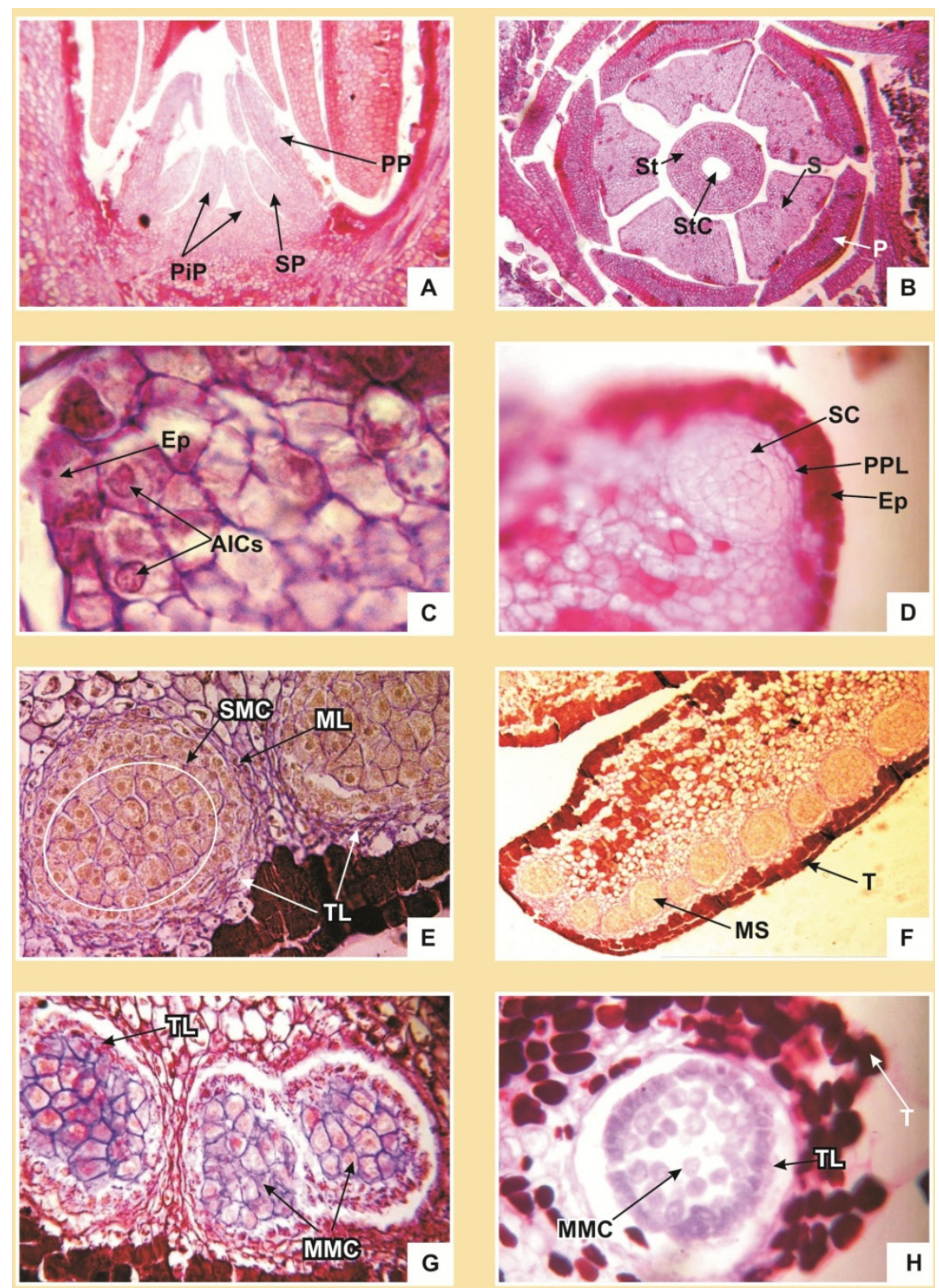

Figure 1.1 (A to H) showing different statges of microsporogenesis A. L. S. of the bud showing stamen primodia formed with at petal base $(200 \times)$ B. T. S. of the bud showing arrangement of stamens and petals $(200 \times)$ C. T. S. of the bud showing two archisporial intial cells (AICs) $(1000 \times)$ D. T. S. of the bud showing development of sporogenous cells (formed by anticlinal and periclinal division of primary sporogenous cells) $(400 \times)$. E. T. S. of the buds showing compactly arranged sporogenous mass of cells and multinucleate single layered tapetum cells and two layers of middle layer $(400 \times)$. F. L.S. of the buds showing multiloculate (septate) anther lobe $(200 \times)$. G. L. S. of the bud showing pectin deposition on the sporogenous cells surrounded by tapetum layer $(400 \times)$. H. T. S.

of the bud showing microspore mother cells surrounded by the tapetal layer and the tannin content in the adjoining cells $(400 \times)$. Where PP: Petal Primordium, SP: Sepal Primordium, PiP: Pistle Primordium, P: Petal, S:

Stamen, St: Style, StC: Stylar canal, Ep: Epidermis, AICs: Archesporial Initial Cells, PPL: Primary Perietal Layer, SC: Sporogenous Cells, SMC: Sporogenous Mass of Cell, MS: Multilocellate Stamen, MMC: Microspore Mother Cell, TL: Tapetum Layer \& T: Tannin 

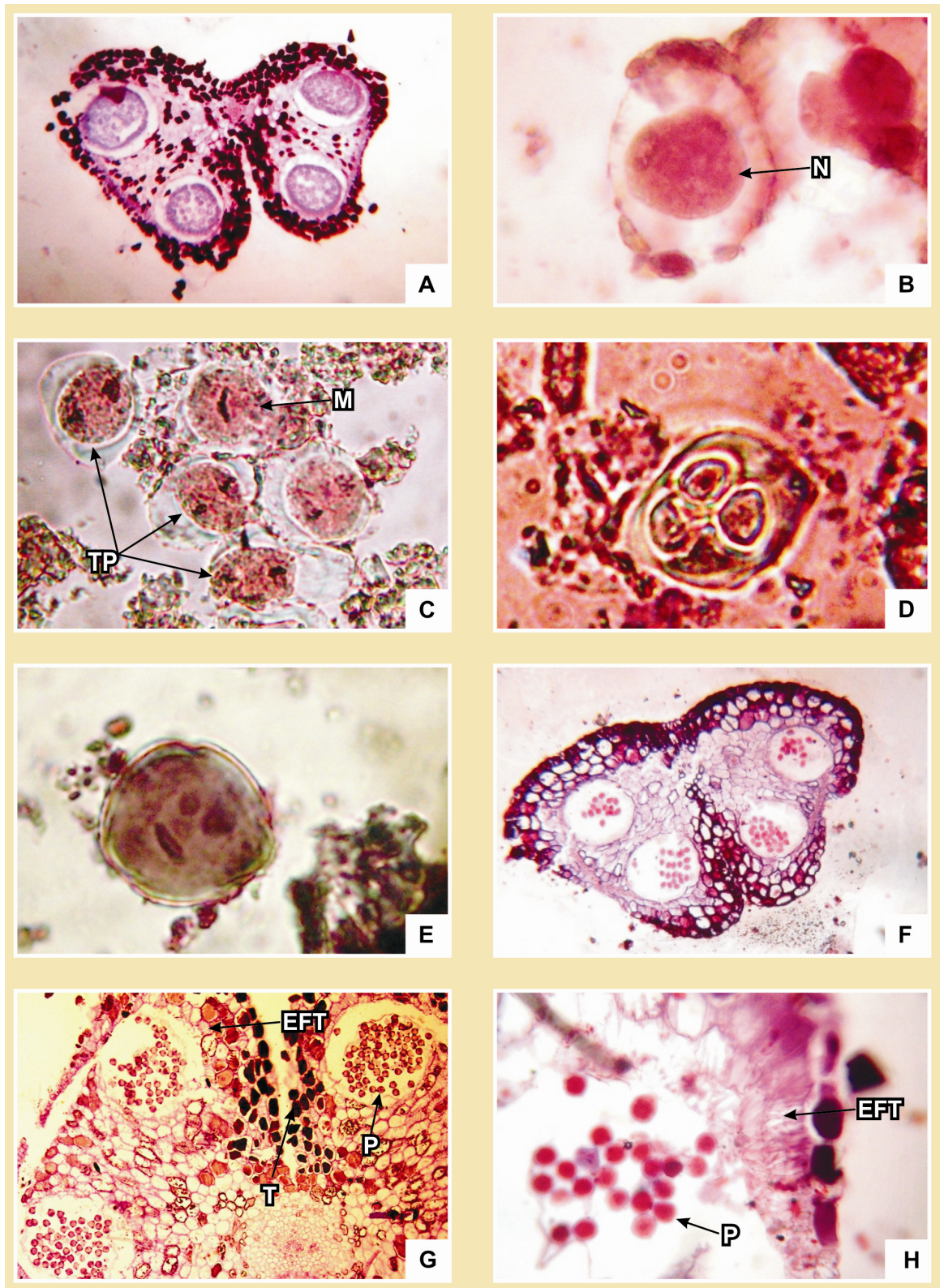

Figure 1.2 (A to $\mathrm{H}$ ) showing different stages of microgemetogenesis A. T. S. of bud showing tannin deposition in vegetative cells except at the form constriction areas $(200 \times)$. B. A microspore mother cell during the prophase of meiosis one showing thin cell wall and dense nuclear material (1000 X). C. Microspore mother cell undergoing meiosis-Metaphase one and Telophase $(1000 \times)$. D. Tetrahedral type of microspore tetrad $(1000 \times)$. E. T. S. of anther showing fully developed tetrasporangiate anther $(1000 \times)$. F. Microspore (pollen grain) showing distinct exine and intine and three germ pores $(200 \times)$. G. T. S. of bud showing developed fibrular thickenings in the endothecial cells $(200 \times)$. H. T. S. of bud showing development of fibrular thickening in almost all vegetative cells and the development of separation layer $(400 \times)$. Where EFT: Endothecial Fibrullar Thickening, T: Tannin, N: Nucleus, M: Metaphase, TP: Telophase

\subsection{Sporogenous Cells (Developmental Stage O-land O-2)}

The primary sporogenous cells divide periclinally and anticlinally to form the sporogenous mass of cells. These cells are compactly arranged without any intercellular space (Figure 1.1 E and F). The stamen is multilocilate (Figure $1.1 \mathrm{~F}$ ). The sporogenous mass of cells was reported in the buds belonging to floral stage O-1. Subsequently, in O-2 stage, some pectin substances accumulate in the cell walls of each sporogenous cells making them distinct (Figure 1.1 G). These cells form microspore mother cells (Figure 1.1 H). The microspore 
mother cells possess thin walls and are found to be uninucleate. Before initiation of meiosis, the microspore mother cells separate from each other (Figure 1.1 H and Figure 1.2 A).

\subsection{Microgemetogenesis}

\subsubsection{Meiosis (Developmental Stage O-3 and O-4)}

Simultaneous type of cell division was reported in A. corniculatum. In this type, the first meiotic division is not followed by wall formation. Consequently, a binucleate cell is formed after meiosis-I but there is no diad stage (Figure $1.2 \mathrm{C}$ ). The two haploid nuclei synchronously undergo the second meiotic division. Callose walls are formed after the second meiotic division, giving rise to a tetrahedral type microspore and were found in the buds of O-4 floral stage (Figure 1.2 D).

\subsubsection{Mature Pollen Grain (Developmental Stage O-5)}

The mature pollen grain wall is composed of two layers i.e. intine and exine. The matured pollen grains have been reported in the buds belonging to O-5 developmental stage (Figure 1.2 E) and are oval to elongated with length $15 \mu \mathrm{m}$ and width $10 \mu \mathrm{m}$. Its surface is smooth and has three germ pores. No deviation in the number of germ pore was observed.

\section{Discussions and Conclusions}

The anthers of Aegiceras are septate (multilocellate) which is in conformity with findings of Karsten (1891). Significant tannin contents have been found in endothecium layer. Mangroves are known to have very high tannin content (Walsh, 1974). Being antimicrobial, tannin provides defense mechanism, in addition, they regulate herbivory (Neilson, Giddins, \& Richards, 1986). Further, Zhang, Lin, Zhou, Wei and Chen (2010) have reported the antioxidant activity of mangrove tannins. It appears that the high tannin content of microsporangial cells protect the cells against herbivores as well as from oxidative damages.

The role of different layers of micrsporangial wall in anther dehiscence had been examined in past. Chatin (1870 a, b, c) and Leclerc, (1985) defined anther dehiscence through septum (disruption of tissue between the microsporangia) and stomium (opening of microsporangia through slit). Subsequently and Keijzer (1986) have defined the five stages of anther dehiscence and also examined the role of fibrillar thickenings in the endothecium cells. He reported that these fibrillar thickenings facilitate development of the centripetal (keeps pollen grains within microsporangia) and centrifugal (exposes the mircosporengia) pressures which lead to anther dehiscence. Present work has also found fibrillar thickenings in the endothecium cells leading to anther dehiscence. These thickenings have also been found in other vegetative cells of anther lobs. Further, the tapetum is of secretary type and, therefore, remained associated with the anther walls and doesn't disintegrate during the microgemetogenesis (pollen grain development) process. Tapetum plays very important role in pollen grains development (Pacini, Franchi, \& Hesse, 1985). Furness and Rudall (2001) found that in most terrestrial plants secretary tapetum dominates. It is believed that mangroves have been developed from terrestrial ancestors.

Meiosis is simultaneous type and the microspore tetrads are tetrahedral type. The tetrahedral type of arrangement is more common in the dicotyledons while the monocotyledons largely have isobilateral type of arrangement. Pollen grains are bi-nucleated at the time of anther dehiscence and have three germ pores. No exception in the number of germ pores in pollen grains has been reported for A. corniculatum during present study. The pollen grains production per flower has been found to range from 0.81 to 5.23 lakh pollen grains with an average of $4.7+0.24$ (SD) lakh pollen grains per flower ( $\mathrm{n}=60$ ) (Pandey, C. N., \& Pandey, R., 2010).

\section{Acknowledgement}

We acknowledge the Ministry of Environment and Forest (MoEF), Government of India for financially supporting the research project "Study of Pollination Biology and Reproductive ecology of Major Mangrove Species of Gujarat" under which the present work carried out. We are also thankful to the Gujarat Ecological Education and Research (GEER) Foundation, Gandhinagar for laboratory facilities and logistic supports etc. We also acknowledge Mr. Hitesh Patel for helping in the laboratory work and sample collections.

\section{References}

Carey, G., \& Fraser, L. (1932). The embryology and seedling development of Aegiceras majus. Proc. Linn. Soc. N.S.W., 57, 341-360.

Carey, G. (1934). Further investigations of the embryology of the viviparous seeds. Proceedings Linneas Society. N. S. W., 59, 392-410. 
Chatin, A. (1870a). Causes de la déhiscence des anthèrs. Compets Rendus Hebdomadaires des Séances del Académie de Science, Paris, Série, D, 70, 201-203.

Chatin, A. (1870b). Causes de la déhiscence des anthèrs. Rŏle de la deuxième membrale. Compets Rendus Hebdomadaires des Séances deĺ Académie de Science, Paris, Série, D, 70, 410-413.

Chatin, A. (1870c). Causes de la déhiscence des anthèrs. Rŏle de la troisème membrane. de la cloison et du connectif. Experiénces sur Í action de Í eau. Compets Rendus Hebdomadaires des Séances del Académie de Science, Paris, Série, D, 70, 644-648.

Cook, M. T. (1907). The embryology of Rhizophora mangle . Bull. Torrey. Bot. Club., 34, 271-277. http://dx.doi.org/10.2307/2479156

Dahlgren. K. V. O. (1916). Zytologische und embryologische studien uber die Reihen Primulales and Plumbaginales. Kgl. Svensk. Vet-Akad, Handl, 56, 1-80.

Debnath, H. S. (2004). Mangroves of Andaman and Nicobar Islands: Taxonomy and Ecology. Pub. Bhisan Singh and Mahendra Pal Singh.

Duke, N. C. (2006). Australia's Mangroves -the authoritative guide to Australia's mangrove plants. Pub. Brisbane: University of Queensland and Norman C. Duke.

Farnsworth, E. (2000). The ecology and physiology of viviparous and recalcitrant seeds. Annual Review of Ecology and Systematics, 31, 107-138. http://dx.doi.org/10.1146/annurev.ecolsys.31.1.107

Furness, C. A., \& Rudall, P. J. (2001). The tapetum in besal angiosperms: early diversity. Int. J. Plant. Sci., 162(2), 375-392. http://dx.doi.org/10.1086/319580

Grindrod, J. (1985). The palynology of mangroves on a prograded shore, Princess Charlotte Bay, North Queensland, Australis. Journal of Biogeography, 12, 323-348. http://dx.doi.org/10.2307/2844865

Hotchkiss, R. D. (1948). A microchemical method resulting in the staining of polysaccharide structure in fixed preparation. Arch. Riochew, 16, 131-141.

Jaramillo, C., \& Bayona, G. (2000). Mangrove distriution during Holocene Tribugá Gulf, Colombia. Biotropica., 32(1), 14-22. http://dx.doi.org/10.1111/j.1744-7429.2000.tb00443.x

Jensen, W. A. (1962). Botanical histochemistry: Principles and Practice. San Franscisco: Fraemar \& Companey.

Jubcosa. A. M. (1982). Developmental morhology of the embryo and seedling of Rhizophora mangle L. (Rhizophoraceae). American Journal of Botany, 69, 1599-1611. http://dx.doi.org/10.2307/2442915

Juncosa. A. M. (1984). Embryiogenesis and developmental morphology of the seedling in Bruguiera exaristata Ding Hou (Rhizophoraceae). American Journal of Botany, 71, 180-191. http://dx.doi.org/10.2307/2443744

Kathiresan, K., \& Rajendran, N. (2005). Mangrove Ecosystems of Indian Ocean Region. Indian Journal of Marine Sciences, 34(1), 104-113.

Karsten, G. (1891). Ober die Mangrove -vegetation im Malayischen Archipel Eine morphologische-biologische studie. Bibliography Botany Stuttgard, 22, 11-18 and 31-41.

Keijzer, C. J. (1987). The process of anther dehiscence and pollen dispersal- I: the opening mechanism of $\begin{array}{lllll}\text { longitudinally dehiscing } & \text { anthers. New. Phytol, } & \text { 105, }\end{array}$ http://dx.doi.org/10.1111/j.1469-8137.1987.tb00886.x

McManus, J. F. (1948). Histological and histochemical use of Periodic Acid. Stain technicol, 23, 99-108.

Neilson, M. J., Giddins, R. L., \& Richards, G. N. (1986). Effect of tannins on the palatability of mangrove leaves to the tropical sesarminid crab Neosarmatium smithi. Marine Ecological Progress Series., 34, 185-186. http://dx.doi.org/10.3354/meps034185

Pacini, E., Franchi, G., \& Hesse, M. (1985). The tapetum: its form, function and possible phylogeny in embryophyta. Pl. Sys. Evol., 149, 155-185. http://dx.doi.org/10.1007/BF00983304

Pandey, C. N., \& Pandey, R. (2009). Study of floristic diversity and natural recruitment of mangroves in selected habitats of South Gujarat (p. 93). GEER Foundation Gandhinagar.

Pandey C. N., \& Pandey, R. (2010). Study of pollination biology and reproductive ecology of major mangrove species in Gujarat (p. 918). Gujarat Ecological Education and Research (GEER) Foundation Gandhinagar. 
Plaziat, J. C., Cavagnetto, C., Koeniguer, J. C., \& Baltzer, F. (2001). History and biogeography of the mangrove ecosystem, based on a critical reassessment of the paleontological record. Wetland Ecology and Management, 9, 161-179. http://dx.doi.org/10.1023/A:1011118204434

Rao, K. S. (1971). Studies in Myrsinaceae-A contribution to the Embryology of Maesa dubea. Wall, pp. $160-166$.

Rull, V. (2001). A quantitative palynological record from the early Miocene of western Venezuela, with Emphasis on Mangroves. Palynology, 25, 109-126. http://dx.doi.org/10.2113/0250109

Schurhoff, P. N. (1926). Zur Pleiophylie der Sympetalen auf Grundihrer Haplo-tenentwicklung. Rep. Spec. nov. reg. Veget. Biith., 41, 3-14.

Tomlinson, P. B. (1986). The Botany of Mangroves (p. 413). New York: Cambridge University Press.

Walsh, G. E. (1974). Mangrove: a review. In R. J. Reinhold \& W. H. Queen (Eds.), Ecology of halophytes (pp. 51-174). New York: Academic Press.

Zhang, L. L., Lin, Y. M., Zhou, H. C., Wei, S. D., \& Chen, J. H. (2010). Condense tannins from mangrove species Kandelia candel and Rhizophora mangle and their antioxidant activity. Molecules, 15, 420-431. http://dx.doi.org/10.3390/molecules 15010420 